Published in final edited form as:

Fam Cancer. 2012 September ; 11(3): 441-447. doi:10.1007/s10689-012-9534-6.

\title{
Cancer spectrum in DNA mismatch repair gene mutation carriers: results from a hospital based Lynch syndrome registry
}

\author{
Mala Pande, \\ Department of Epidemiology, The University of Texas MD Anderson Cancer Center, Unit 1365, \\ PO Box 301439, Houston, TX 77230-1439, USA
}

Chongjuan Wei,

Department of Epidemiology, The University of Texas MD Anderson Cancer Center, Unit 1365, PO Box 301439, Houston, TX 77230-1439, USA

Jinyun Chen,

Department of Epidemiology, The University of Texas MD Anderson Cancer Center, Unit 1365, PO Box 301439, Houston, TX 77230-1439, USA

Christopher I. Amos,

Department of Genetics, The University of Texas MD Anderson Cancer Center, Houston, TX 77030, USA

Patrick M. Lynch,

Department of Gastroenterology, Hepatology and Nutrition, The University of Texas MD

Anderson Cancer Center, Houston, TX 77030, USA

Karen H. Lu,

Department of Gynecologic Oncology and Reproductive Medicine, The University of Texas MD Anderson Cancer Center, Houston, TX 77030, USA

Laura A. Lucio,

Department of Epidemiology, The University of Texas MD Anderson Cancer Center, Unit 1365, PO Box 301439, Houston, TX 77230-1439, USA

Stephanie G. Boyd-Rogers,

Department of Gynecologic Oncology and Reproductive Medicine, The University of Texas MD Anderson Cancer Center, Houston, TX 77030, USA

Sarah A. Bannon,

Department of Surgical Oncology, The University of Texas MD Anderson Cancer Center, Houston, TX 77030, USA

Maureen E. Mork, and

Department of Gastroenterology, Hepatology and Nutrition, The University of Texas MD

Anderson Cancer Center, Houston, TX 77030, USA

Marsha L. Frazier

Department of Epidemiology, The University of Texas MD Anderson Cancer Center, Unit 1365, PO Box 301439, Houston, TX 77230-1439, USA

Marsha L. Frazier: mlfrazier@mdanderson.org

\section{Abstract}

(C) Springer Science+Business Media B.V. 2012

Correspondence to: Marsha L. Frazier, mlfrazier@mdanderson . org. 
The spectrum of cancers seen in a hospital based Lynch syndrome registry of mismatch repair gene mutation carriers was examined to determine the distribution of cancers and examine excess cancer risk. Overall there were 504 cancers recorded in 368 mutation carriers from 176 families. These included $236(46.8 \%)$ colorectal and $268(53.2 \%)$ extracolonic cancers. MLH1 mutation carriers had a higher frequency of colorectal cancers whereas MSH2, MSH6 and PMS2 mutation carriers had more extracolonic cancers although these differences were not statistically significant. Men had fewer extracolonic cancers than colorectal (45.3 vs. $54.7 \%$ ), whereas women had more extracolonic than colorectal cancers (59.0 vs. $41.0 \%)$. The mean age at diagnosis overall for extracolonic cancers was older than for colorectal, 49.1 versus 44.8 years $(P \leq 0.001)$. As expected, the index cancer was colorectal in $58.1 \%$ of patients and among the extracolonic index cancers, endometrial was the most common $(13.8 \%)$. A significant number of non-Lynch syndrome index cancers were recorded including breast $(n=5)$ prostate $(n=3)$, thyroid $(n=3)$, cervix $(n=3)$, melanoma $(n=3)$, and 1 case each of thymoma, sinus cavity, and adenocarcinoma of the lung. However, standardized incidence ratios calculated to assess excess cancer risk showed that only those cancers known to be associated with Lynch syndrome were significant in our sample. We found that Lynch syndrome patients can often present with cancers that are not considered part of Lynch syndrome. This has clinical relevance both for diagnosis of Lynch syndrome and surveillance for cancers of different sites during follow-up of these patients.

\section{Keywords}

Lynch syndrome cancers; Colorectal; Extracolonic; Index cancer

\section{Introduction}

Lynch syndrome (LS), also known as hereditary non-polyposis colon cancer syndrome (HNPCC), is one of the most common forms of inherited predisposition to colorectal cancer (CRC), representing 1-7\% of all CRC [1-3]. More recently the prevalence of LS has been determined to be one out of every 35 CRC patients $(2.8 ; 95 \% \mathrm{CI}, 2.1-3.8 \%)$ [4]. LS is characterized by an earlier age at diagnosis of CRC (median age of 44) $[5,6]$ than that in sporadic CRC (70 years) (http://seer.cancer.gov/csr/1975_2008/results_single/sect_01_table. 11_2pgs.pdf). Individuals with LS have $80 \%$ probability of developing CRC by the age of 65 and are at elevated risk of developing a second primary CRC [7]. In addition, they have increased risk of developing various extracolonic malignancies. For example, affected women have a 50-60\% risk of developing endometrial cancer. Cancer at other primary sites including stomach, ovaries, small intestine, urological tract, pancreas, brain and skin [1,8, 9] has also been documented in families with LS. Among those extra-colonic malignancies, endometrial, renal pelvis/ureter, and small intestinal cancers have the highest relative risk and are considered as part of LS spectrum [10]. Also part of the LS spectrum are sebaceous gland neoplasms and keratoacanthomas along with low grade visceral malignancies that are classified as a subtype of LS called Muir-Torre syndrome [11, 12].

Germline mutations in DNA mismatch repair (MMR) genes are responsible for LS. The main genes involved are $M L H 1, M S H 2, M S H 6, P M S 1$ and $P M S 2$ [10, 13, 14]. Studies revealed some evidence for a relationship between the involved MMR gene and the cancer spectrum. For example, MSH2 mutation carriers appear to have a higher risk of developing extra-colonic cancer than individuals with MLH1 mutation $[7,15,16]$. In addition, the frequency and the types of mutations are reported to differ in different geographical areas, therefore, the frequency of extra-colonic cancer associated with LS may be different in different populations [17-19]. 
To better characterize LS and further study the cancer spectrum related to LS, in this study we have evaluated the frequency of extra-colonic cancer in 176 unrelated LS families enrolled in a hospital based LS registry.

\section{Methods}

In this descriptive analysis, we studied LS patients and family members with confirmed pathogenic DNA mismatch repair (MMR) mutations. These were all participants who had consented to participate in an ongoing IRB approved study "Molecular Genetics of HNPCC" and were recruited between September 1994 and June 2011 at MD Anderson Cancer Center. Probands were largely recruited from the gastroenterology and gynecologic oncology clinics at MD Anderson Cancer Center and also through the genetic counselors at the Clinical Cancer Genetics Clinic. Family members were consented and enrolled through the probands. The subjects included both cancer affected and cancer free MMR gene mutation carriers. Demographic characteristics and cancer history were self reported through a self administered structured questionnaire. Whenever possible, cancer diagnoses were further confirmed from medical records and pathology reports.

\section{Statistical analysis}

Demographic characteristics and MMR gene mutated were compared between the cancer affected and cancer free mutation carriers using simple $\chi^{2}$ statistics. The distribution of colonic versus extracolonic cancers was compared by sex, race, age and MMR mutation. Furthermore, the distribution of cancers and the median age at diagnosis for each class of cancers in the study sample were explored. Additionally, cancer specific standardized incidence ratios (SIRs) and $95 \%$ confidence intervals were computed to determine the excess cancers in MMR mutation carriers compared to noncarriers, and in the subset of mutation positive relatives. We excluded the probands in the subset analysis for cancer specific SIRs to overcome the significant bias associated with probands, since probands are ascertained largely because of being cancer affected, resulting in a high cancer rate in probands. SIRs were computed as the ratio of the observed number of cancer cases to the expected number using the Cohort Analysis for Genetic Epidemiology (CAGE) software program [20]. The expected number of cancers was determined using sex, age and birth cohort specific rates from the Surveillance Epidemiology and End Results (SEER) data. The CAGE program uses first primary cancers from SEER to compute the expected number of cancers so analyses were limited to calculating SIRs for the first primary cancer of each site other than non-melanoma skin cancer, which is excluded in SEER.

\section{Results}

The study included 368 MMR mutation carriers from 176 families, of which $59 \%$ were women. The subjects were predominantly non-Hispanic white $(83.4 \%)$. The ages ranged from 18 to 93 years (median 49 years). Roughly $30 \%$ of the mutation carriers were cancer free. There were no significant differences between the cancer affected and cancer free mutation carriers by sex, race, age (at index cancer diagnosis for CRC cases and at last contact for cancer free subjects), MMR gene mutated or the mutation type (Table 1). There were a total of 165 probands (for whom we had data), of which $142(86 \%)$ had cancer, and 203 mutation carrying family members, of which 118 (58 \%) were cancer cases. The number of family members per family ranged from 1 to 15 . The number of cancers per person ranged between 1 and 7, with roughly half (51.6\%) diagnosed with only 1 cancer. The cancers included in the analysis were diagnosed between 1948 and 2010 (median 1997). A total of 504 cancers were recorded in the $368 \mathrm{MMR}$ gene mutation carriers. There were $236(46.8 \%)$ colorectal and $268(53.2 \%)$ extracolonic cancers overall. However, CRC was 
the most common index cancer, $\mathrm{n}=151(58.1 \%)$ as compared to $109(41.9 \%)$ index extracolonic cancers. Table 2 outlines the comparison between the colorectal and extracolonic cancers by sex, race, MMR gene mutated, type of MMR gene mutation and age at diagnosis of any cancer. These results are also presented as Fig. 1a-e. Men had fewer extracolonic cancers than colorectal (44.6 vs. $55.4 \%$ ), whereas women had more extracolonic cancers than colorectal $(58.9$ vs. $41.1 \%),(P=0.002)$. MLH1 mutation carriers had more colorectal cancers but there were more extracolonic than colorectal cancers in MSH2 and MSH6 and PMS2 mutation carriers (difference not statistically significant). The mean age at diagnosis for extracolonic cancers was older than for colorectal, 49.1 versus 44.8 years $(P \leq 0.001)$. Distribution of median age at diagnosis and the minimum and maximum age at diagnosis for each of the cancers is shown in Fig. 1f. and distribution and types of all cancers seen in this cohort is described in Figs. 2a and $b$.

Many rare cancers presented as index cancers as outlined in Table 3 . The index tumor was not a LS related tumor in $26(10 \%)$ cancer patients.

SIR values were significantly higher for cancers of the colon, rectum, endometrium, ovaries, kidneys, bladder, stomach and small intestine. However, for the non-Lynch syndrome related cancers like breast, prostate, melanoma, cervix, lung, sinus cavity and thyroid, the SIR values were not significant (Table 4).

\section{Discussion}

In this report of cancers affecting 368 MMR gene mutation carriers in a hospital based Lynch syndrome registry, we analyzed the tumor spectrum to determine the frequency and distribution of index and multiple cancers. We compared the distribution of colonic and extracolonic cancers by sex, race, age and MMR mutation, and our study confirmed previously reported findings that extracolonic cancers are more common in women perhaps because of their predisposition to endometrial and ovarian cancers [1] and that extracolonic cancers are more likely to be associated with MSH2 and MSH6 mutation carriers [21].

Surveillance of these high risk patients entails not just screening for colorectal and endometrial cancer but also cancers at other sites. The Lynch syndrome spectrum of cancers besides colorectal and endometrial includes stomach, ovaries, small intestine, urological tract, pancreas, brain and skin. Overall in our sample, $\sim 10 \%$ of the index tumors were located at sites that are not considered to be part of the Lynch syndrome spectrum. For example, there were 5 patients that presented with breast cancer as the primary cancer and 3 patients that presented with prostate cancer. Whether breast cancer is part of Lynch syndrome tumors is controversial with evidence both in support of $[22,23]$ and against it $[24,25,26]$. Similarly there have been reports suggesting that prostate cancer may be a part of the Lynch syndrome tumor spectrum $[8,27,28]$. Although there were a significant number of breast and prostate cancer cases in our study, the SIR for these cancers were not significant as these are relatively common cancers in the general population. However, seeing that these tumors were detected in MMR mutation carriers, and were seen in much younger women (median age of onset for breast cancer: 36 years) and men (median age of onset for prostate cancer: 65 years) than expected, may suggest a high index of suspicion for considering Lynch syndrome in early onset patients presenting with these cancers.

Several rare non-Lynch syndrome index cancers were recorded in this population. These included thyroid $(n=3,1.15 \%)$, cervix/vagina $(n=3,1.15 \%)$, melanoma $(n=3,1.15 \%)$ and 1 case each of thymoma, carcinoma of the sinus cavity, and adenocarcinoma of the lung. In addition, there was 1 index brain tumor and 4 patients presented with metastatic disease 
(lung, liver, unknown primary). With MD Anderson being a tertiary care hospital, it is possible that these cases may not represent the population spectrum of LS cancers.

The strengths of our study include a large sample size of MMR gene mutation carriers from 176 unrelated families and detailed recording of cancer history.

In conclusion, we found that the distribution of cancers in patients in our hospital based Lynch syndrome registry was similar to what has been previously reported. However, the findings regarding index cancers seen in our study suggest that a significant number of Lynch syndrome patients can present with primary tumors that are not part of the Lynch syndrome spectrum.

\section{Acknowledgments}

This research was supported in part by the National Institutes of Health through MD Anderson's Cancer Center Support Grant (CA016672) which supports the Biospecimen and Extraction Resource and the Human Pedigree Analysis Resource service cores; and research grant 5R01CA070759-11.

\section{References}

1. Geary J, Sasieni P, Houlston R, Izatt L, Eeles R, Payne SJ, Fisher S, Hodgson SV. Gene-related cancer spectrum in families with hereditary non-polyposis colorectal cancer (HNPCC). Fam Cancer. 2008; 7:163-172. [PubMed: 17939062]

2. Pinol V, Castells A, Andreu M, Castellvi-Bel S, Alenda C, Llor X, Xicola RM, Rodriguez-Moranta F, Paya A, Jover R, Bessa X. Accuracy of revised Bethesda guidelines, microsatellite instability, and immunohistochemistry for the identification of patients with hereditary nonpolyposis colorectal cancer. JAMA. 2005; 293:1986-1994. [PubMed: 15855432]

3. Salovaara R, Loukola A, Kristo P, Kaariainen H, Ahtola H, Eskelinen M, Harkonen N, Julkunen R, Kangas E, Ojala S, Tulikoura J, Valkamo E, Jarvinen H, Mecklin JP, Aaltonen LA, de la Chapelle A. Population-based molecular detection of hereditary nonpolyposis colorectal cancer. J Clin Oncol. 2000; 18:2193-2200. [PubMed: 10829038]

4. Hampel H, Frankel WL, Martin E, Arnold M, Khanduja K, Kuebler P, Clendenning M, Sotamaa K, Prior T, Westman JA, Panescu J, Fix D, Lockman J, LaJeunesse J, Comeras I, de la Chapelle A. Feasibility of screening for Lynch syndrome among patients with colorectal cancer. J Clin Oncol. 2008; 26:5783-5788. [PubMed: 18809606]

5. Lynch HT, Ens J, Lynch JF, Watson P. Tumor variation in three extended Lynch syndrome II kindreds. Am J Gastroenterol. 1988; 83:741-747. [PubMed: 3381806]

6. Lynch HT, Lynch JF. The Lynch syndromes. Curr Opin Oncol. 1993; 5:687-696. [PubMed: 8364086]

7. Lin KM, Shashidharan M, Ternent CA, Thorson AG, Blatchford GJ, Christensen MA, Lanspa SJ, Lemon SJ, Watson P, Lynch HT. Colorectal and extracolonic cancer variations in MLH1/MSH2 hereditary nonpolyposis colorectal cancer kindreds and the general population. Dis Colon Rectum. 1998; 41:428-433. [PubMed: 9559626]

8. da Silva FC, de Oliveira LP, Santos EM, Nakagawa WT, Aguiar JS, Valentin MD, Rossi BM, de Oliveira FF. Frequency of extracolonic tumors in Brazilian families with Lynch syndrome: analysis of a hereditary colorectal cancer institutional registry. Fam Cancer. 2010; 9:563-570. [PubMed: 20697958]

9. Watson P, Riley B. The tumor spectrum in the Lynch syndrome. Fam Cancer. 2005; 4:245-248. [PubMed: 16136385]

10. Vasen HF, Watson P, Mecklin JP, Lynch HT. New clinical criteria for hereditary nonpolyposis colorectal cancer (HNPCC, Lynch syndrome) proposed by the international collaborative group on HNPCC. Gastroenterology. 1999; 116:1453-1456. [PubMed: 10348829]

11. Lynch HT, Fusaro RM, Roberts L, Voorhees GJ, Lynch JF. Muir-Torre syndrome in several members of a family with a variant of the Cancer Family Syndrome. Br J Dermatol. 1985; 113:295-301. [PubMed: 4063166] 
12. Schwartz RA, Torre DP. The Muir-Torre syndrome: a 25-year retrospect. J Am Acad Dermatol. 1995; 33:90-104. [PubMed: 7601953]

13. Giardiello FM. Genetic testing in hereditary colorectal cancer. JAMA. 1997; 278:1278-1281. [PubMed: 9333271]

14. Peltomaki P, Vasen HF. Mutations predisposing to hereditary nonpolyposis colorectal cancer: database and results of a collaborative study. The International collaborative group on hereditary nonpolyposis colorectal cancer. Gastroenterology. 1997; 113:1146-1158. [PubMed: 9322509]

15. Lynch HT, Smyrk TC, Watson P, Lanspa SJ, Lynch JF, Lynch PM, Cavalieri RJ, Boland CR. Genetics, natural history, tumor spectrum, and pathology of hereditary nonpolyposis colorectal cancer: an updated review. Gastroenterology. 1993; 104:1535-1549. [PubMed: 8482467]

16. Vasen HF, Stormorken A, Menko FH, Nagengast FM, Kleibeuker JH, Griffioen G, Taal BG, Moller P, Wijnen JT. MSH2 mutation carriers are at higher risk of cancer than MLH1 mutation carriers: a study of hereditary nonpolyposis colorectal cancer families. J Clin Oncol. 2001; 19:4074-4080. [PubMed: 11600610]

17. Bai YQ, Akiyama Y, Nagasaki H, Lu SL, Arai T, Morisaki T, Kitamura M, Muto A, Nagashima M, Nomizu T, Iwama T, Itoh H, Baba S, Iwai T, Yuasa Y. Predominant germ-line mutation of the hMSH2 gene in Japanese hereditary non-polyposis colorectal cancer kindreds. Int J Cancer. 1999; 82:512-515. [PubMed: 10404063]

18. Kim JC, Kim HC, Roh SA, Koo KH, Lee DH, Yu CS, Lee JH, Kim TW, Lee HL, Beck NE, Bodmer WF. hMLH1 and hMSH2 mutations in families with familial clustering of gastric cancer and hereditary non-polyposis colorectal cancer. Cancer Detect Prev. 2001; 25:503-510. [PubMed: 12132870]

19. Rossi BM, Lopes A, Oliveira FF, Nakagawa WT, Napoli Ferreira CC, Casali Da Rocha JC, Simpson CC, Simpson AJ. hMLH1 and hMSH2 gene mutation in Brazilian families with suspected hereditary nonpolyposis colorectal cancer. Ann Surg Oncol. 2002; 9:555-561. [PubMed: 12095971]

20. Liu, M.; Scheurer, ME.; Bondy, ML.; Strom, SS.; Amos, CI.; Etzel, CJ. Extension of the cohort analysis for genetic epidemiology program to assess excess risk of cancer. American Statistical Association. Proceeding of the 2007 Joint Statistical Meeting; 2007. p. 2546-2550.

21. Bandipalliam P, Garber J, Kolodner RD, Syngal S. Clinical presentation correlates with the type of mismatch repair gene involved in hereditary nonpolyposis colon cancer. Gastroenterology. 2004; 126:936-937. [PubMed: 14988860]

22. Jensen UB, Sunde L, Timshel S, Halvarsson B, Nissen A, Bernstein I, Nilbert M. Mismatch repair defective breast cancer in the hereditary nonpolyposis colorectal cancer syndrome. Breast Cancer Res Treat. 2010; 120:777-782. [PubMed: 19575290]

23. Walsh MD, Buchanan DD, Cummings MC, Pearson SA, Arnold ST, Clendenning M, Walters R, McKeone DM, Spurdle AB, Hopper JL, Jenkins MA, Phillips KD, Suthers GK, George J, Goldblatt J, Muir A, Tucker K, Pelzer E, Gattas MR, Woodall S, Parry S, Macrae FA, Haile RW, Baron JA, Potter JD, Le ML, Bapat B, Thibodeau SN, Lindor NM, McGuckin MA, Young JP. Lynch syndrome-associated breast cancers: clinicopathologic characteristics of a case series from the colon cancer family registry. Clin Cancer Res. 2010; 16:2214-2224. [PubMed: 20215533]

24. Muller A, Edmonston TB, Corao DA, Rose DG, Palazzo JP, Becker H, Fry RD, Rueschoff J, Fishel R. Exclusion of breast cancer as an integral tumor of hereditary nonpolyposis colorectal cancer. Cancer Res. 2002; 62:1014-1019. [PubMed: 11861375]

25. de Leeuw WJ, van PM, Tollenaar RA, Cornelisse CJ, Vasen HF, Morreau H. Correspondence re: A. Muller et al., Exclusion of breast cancer as an integral tumor of hereditary nonpolyposis colorectal cancer. Cancer Res. 2003; 63:1148-1149. [PubMed: 12615735]

26. Vasen HF, Morreau H, Nortier JW. Is breast cancer part of the tumor spectrum of hereditary nonpolyposis colorectal cancer? Am J Hum Genet. 2001; 68:1533-1535. [PubMed: 11359214]

27. Bauer CM, Ray AM, Halstead-Nussloch BA, Dekker RG, Raymond VM, Gruber SB, Cooney KA. Hereditary prostate cancer as a feature of Lynch syndrome. Fam Cancer. 2011; 10:37-42. [PubMed: 20872076] 
28. Grindedal EM, Moller P, Eeles R, Stormorken AT, Bowitz-Lothe IM, Landro SM, Clark N, Kvale R, Shanley S, Maehle L. Germ-line mutations in mismatch repair genes associated with prostate cancer. Cancer Epidemiol Biomarkers Prev. 2009; 18:2460-2467. [PubMed: 19723918] 
A

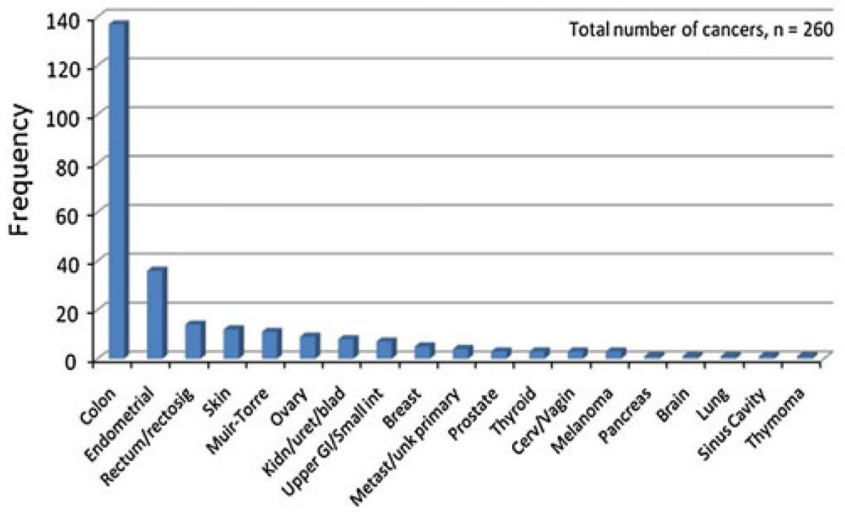

C

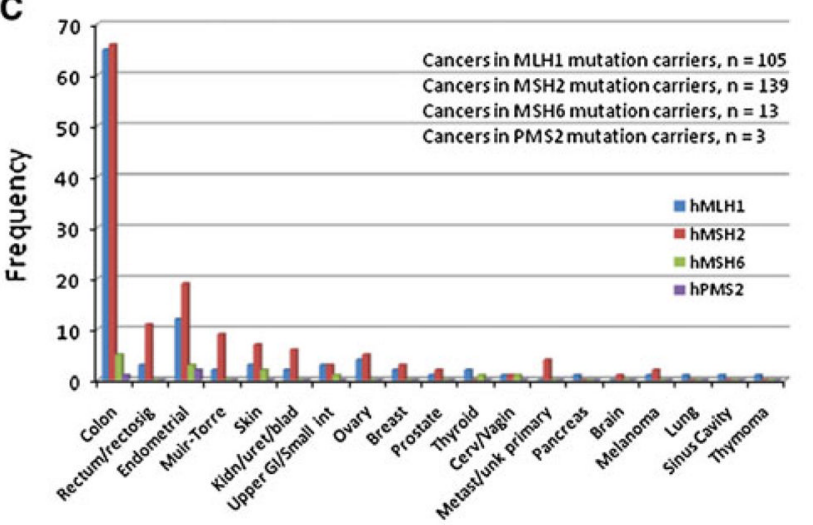

E

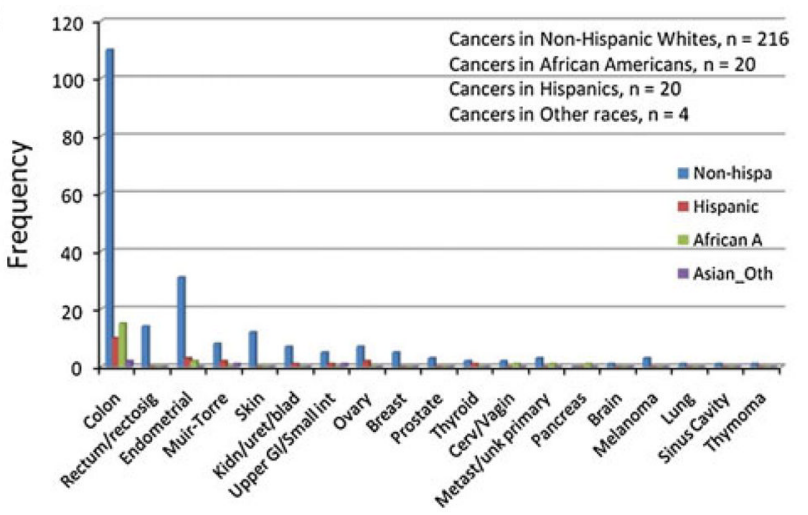

B

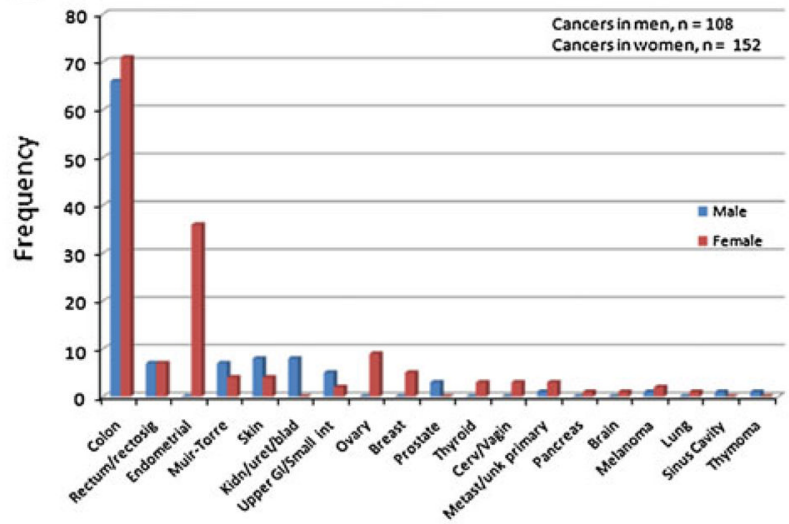

D

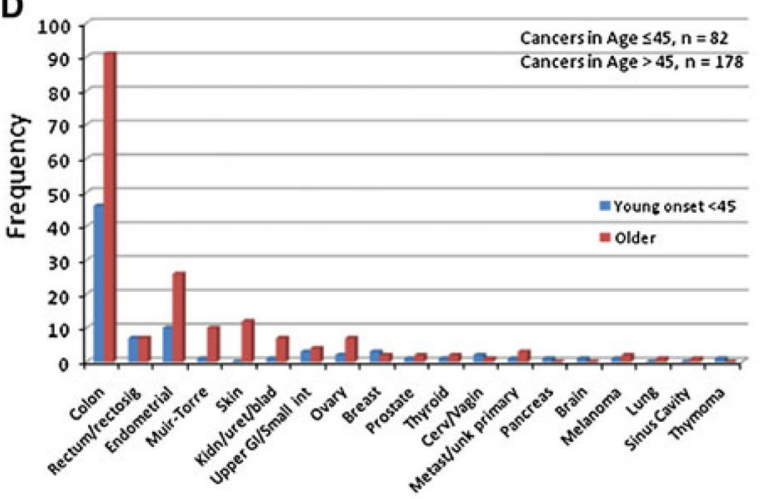

$\mathbf{F}$

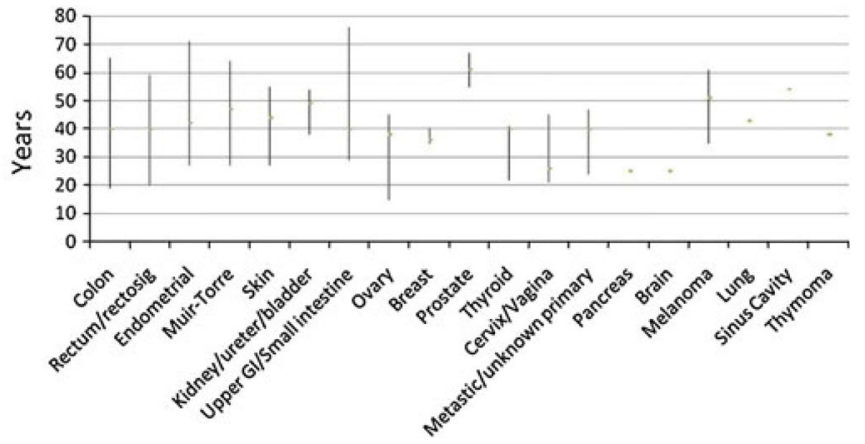

Fig. 1.

Distribution of index cancers by, $\mathbf{a}$ all index cancers, $\mathbf{b}$ sex, $\mathbf{c}$ MMR gene, $\mathbf{d}$ age, $\mathbf{e}$ race, $\mathbf{f}$ median age at diagnosis (lines represent minimum and maximum ages at diagnosis) 
A

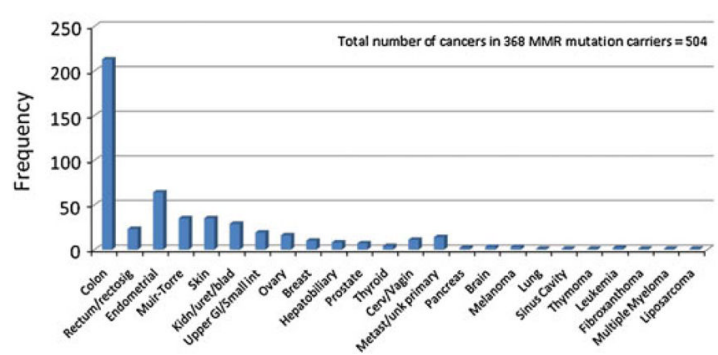

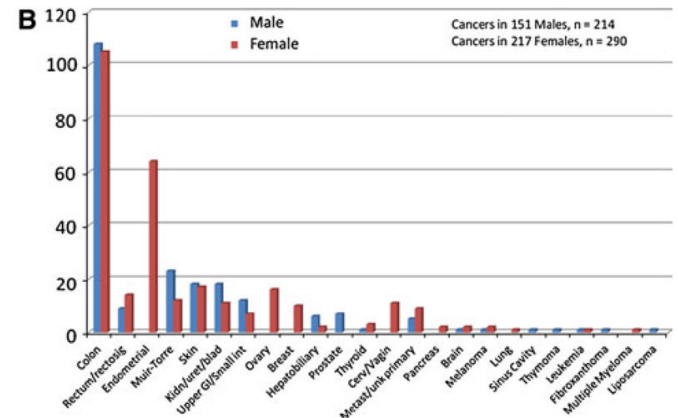

Fig. 2.

Distribution of all cancers by, a all cancers, $\mathbf{b}$ sex 
Table 1

Demographic characteristics of MMR mutation carriers

\begin{tabular}{|c|c|c|c|c|}
\hline & $\begin{array}{c}\text { Total } \\
N=368\end{array}$ & $\begin{array}{l}\text { Cancer } \\
N=\mathbf{2 6 0}\end{array}$ & $\begin{array}{l}\text { No cancer } \\
N=108\end{array}$ & $P$ \\
\hline \multicolumn{5}{|l|}{$\operatorname{Sex}[N(\%)]$} \\
\hline Male & $151(41.0)$ & $108(71.5)$ & $43(28.5)$ & 0.76 \\
\hline Female & $217(59.0)$ & $152(70.0)$ & $65(30.0)$ & \\
\hline \multicolumn{5}{|l|}{ Race $[\mathrm{N}(\%)]$} \\
\hline White & $307(83.4)$ & $216(70.4)$ & $91(29.6)$ & 0.51 \\
\hline African American & $26(7.1)$ & $20(76.9)$ & $6(23.1)$ & \\
\hline Hispanic & $27(7.3)$ & $20(74.1)$ & $7(25.9)$ & \\
\hline Other & $8(2.2)$ & $4(50.0)$ & $4(50.0)$ & \\
\hline \multicolumn{5}{|c|}{ MMR mutation $[\mathrm{N}(\%)]$} \\
\hline hMLH1 & $152(41.3)$ & $105(69.1)$ & $47(30.9)$ & 0.51 \\
\hline hMSH2 & $197(53.5)$ & $139(70.6)$ & $58(29.4)$ & \\
\hline hMSH6 & $16(4.4)$ & $13(81.3)$ & $3(18.7)$ & \\
\hline hPMS2 & $3(0.8)$ & $3(100.0)$ & $0(0.0)$ & \\
\hline \multicolumn{5}{|c|}{ MMR mutation type [N (\%)] } \\
\hline Deletion & $116(31.5)$ & $88(75.9)$ & $28(24.1)$ & 0.48 \\
\hline Duplication & $2(0.5)$ & $2(100.0)$ & $0(0)$ & \\
\hline Frameshift & $2(0.5)$ & $2(100.0)$ & $0(0)$ & \\
\hline Insertion & $29(7.9)$ & $22(75.9)$ & $7(24.1)$ & \\
\hline Missense & $50(13.6)$ & $32(64.00$ & $18(36.0)$ & \\
\hline Nonsense & $73(19.8)$ & $49(67.1)$ & $24(32.9)$ & \\
\hline Splice & $96(26.1)$ & $65(67.7)$ & $31(32.3)$ & \\
\hline \multicolumn{5}{|c|}{ Location of index cancer $[\mathrm{N}(\%)]$} \\
\hline Colorectal & $151(58.1)$ & $151(58.1)$ & - & \\
\hline Extracolonic & $109(41.9)$ & $109(41.9)$ & - & \\
\hline \multicolumn{5}{|c|}{ Age at diagnosis of index cancer (cases) or age at last contact (if no cancer) } \\
\hline Mean $\pm \mathrm{SD}$ & $41.2(10.6)$ & $41.3(10.0)$ & $40.9(11.8)$ & 0.75 \\
\hline
\end{tabular}

Fam Cancer. Author manuscript; available in PMC 2013 September 01. 
Table 2

Distribution of colorectal and extracolonic cancers

\begin{tabular}{|c|c|c|c|c|}
\hline & $\begin{array}{c}\text { Total cancers } \\
\mathbf{N}=\mathbf{5 0 4}\end{array}$ & $\begin{array}{l}\text { Colonic } \\
N=236\end{array}$ & $\begin{array}{c}\text { Extracolonic } \\
N=268\end{array}$ & $\boldsymbol{P}$ \\
\hline \multicolumn{5}{|l|}{$\operatorname{Sex}[N(\%)]$} \\
\hline Male & $214(42.5)$ & $117(54.7)$ & $97(45.3)$ & 0.002 \\
\hline Female & $290(57.5)$ & $119(41.0)$ & $171(59.0)$ & \\
\hline \multicolumn{5}{|l|}{ Race $[\mathrm{N}(\%)]$} \\
\hline White & $417(82.8)$ & $196(47.0)$ & $221(53.0)$ & 0.87 \\
\hline African & $44(8.7)$ & $22(50.0)$ & $22(50.0)$ & \\
\hline \multicolumn{5}{|l|}{ American } \\
\hline Hispanic & $39(7.7)$ & $16(41.0)$ & $23(59.0)$ & \\
\hline Other & $4(0.8)$ & $2(50.0)$ & $2(50.0)$ & \\
\hline \multicolumn{5}{|c|}{ MMR mutation [N (\%)] } \\
\hline hMLH1 & $186(36.9)$ & $97(52.2)$ & $89(47.8)$ & 0.1 \\
\hline hMSH2 & $287(56.9)$ & $130(45.3)$ & $157(54.7)$ & \\
\hline hMSH6 & $28(5.6)$ & $8(28.6)$ & $20(71.4)$ & \\
\hline hPMS2 & $3(0.6)$ & $1(33.3)$ & $2(66.7)$ & \\
\hline \multicolumn{5}{|c|}{ MMR mutation type $[\mathrm{N}(\%)]$} \\
\hline Deletion & $187(37.1)$ & $86(46.0)$ & $101(54.0)$ & 0.1 \\
\hline Duplication & $2(0.4)$ & $0(0)$ & $2(100.0)$ & \\
\hline Frameshift & $3(0.6)$ & $2(66.7)$ & $1(33.3)$ & \\
\hline Insertion & $39(7.7)$ & $23(59.0)$ & $16(41.0)$ & \\
\hline Missense & $50(9.9)$ & $19(38.0)$ & $31(62.0)$ & \\
\hline Nonsense & $96(19.1)$ & $47(49.0)$ & $49(51.0)$ & \\
\hline Splice & $127(25.2)$ & $76(59.8)$ & $51(40.2)$ & \\
\hline \multicolumn{5}{|c|}{ Age at diagnosis of any cancer } \\
\hline Mean $\pm \mathrm{SD}$ & $47.1(12.3)$ & $44.8(12.1)$ & $49.1(12.2)$ & 0.0001 \\
\hline
\end{tabular}

Fam Cancer. Author manuscript; available in PMC 2013 September 01. 


\section{Table 3}

Distribution of index cancers

\begin{tabular}{|c|c|c|}
\hline Cancer type & Frequency & Percent \\
\hline Colon & 137 & 52.69 \\
\hline Rectum/rectosigmoid & 14 & 5.38 \\
\hline Endometrial & 36 & 13.85 \\
\hline Muir-Torre $^{a}$ & 11 & 4.23 \\
\hline Skin & 12 & 4.62 \\
\hline Kidney/ureter/bladder & 8 & 3.08 \\
\hline Upper GI/stomach/small intestine & 7 & 2.69 \\
\hline Ovary & 9 & 3.46 \\
\hline Breast $b$ & 5 & 1.92 \\
\hline Prostate ${ }^{b}$ & 3 & 1.15 \\
\hline Thyroid $^{b}$ & 3 & 1.15 \\
\hline Cervix/vagina $b$ & 3 & 1.15 \\
\hline Metastic/unknown primary & 4 & 1.54 \\
\hline Pancreas & 1 & 0.38 \\
\hline Brain & 1 & 0.38 \\
\hline Melanoma $b$ & 3 & 1.15 \\
\hline Lung $b$ & 1 & 0.38 \\
\hline Sinus cavity $b$ & 1 & 0.38 \\
\hline Thymoma $b$ & 1 & 0.38 \\
\hline Total & 260 & 100 \\
\hline
\end{tabular}

${ }^{a}$ Muir-Torre is a sub-type of Lynch syndrome characterized by sebaceous neoplasms of the skin often with keratoacanthomas and low-grade visceral malignancies

$b_{\text {Not part of Lynch syndrome spectrum of cancers }}$ 


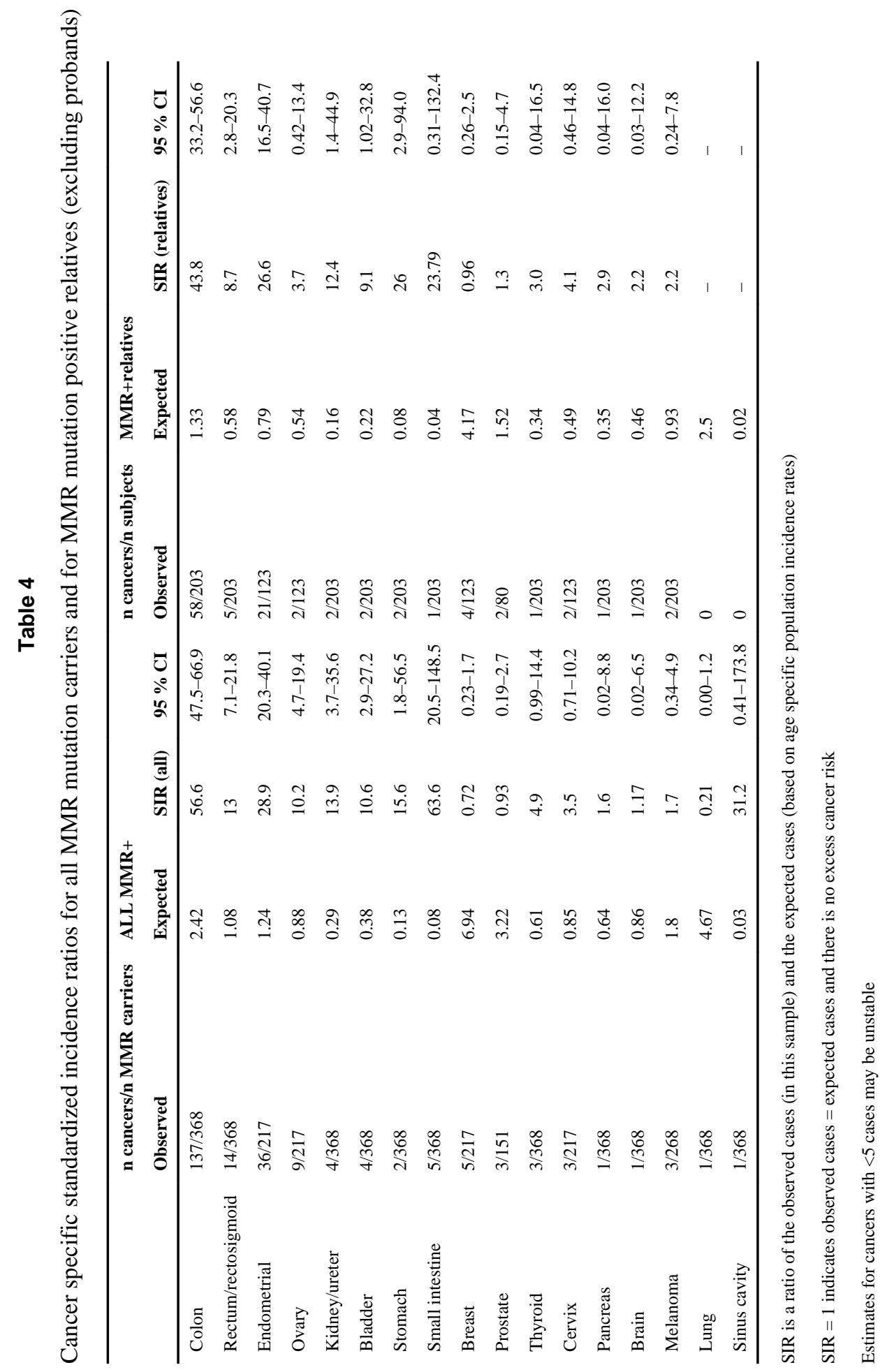

Fam Cancer. Author manuscript; available in PMC 2013 September 01. 